\title{
Catalytical Properties of Free and Immobilized Aspergillus niger Tannase
}

\author{
Abril Flores-Maltos, Luis V. Rodríguez-Durán, Jacqueline Renovato, Juan C. Contreras, \\ Raúl Rodríguez, and Cristóbal N. Aguilar
}

Department of Food Science and Technology, School of Chemistry, Autonomous University of Coahuila, Boulevard V. Carranza
and González Lobo s/n, 25280 Saltillo, COAH, Mexico

Correspondence should be addressed to Cristóbal N. Aguilar, cn_aguilar@yahoo.com

Received 15 April 2011; Accepted 13 July 2011

Academic Editor: Alane Beatriz Vermelho

Copyright ( $) 2011$ Abril Flores-Maltos et al. This is an open access article distributed under the Creative Commons Attribution License, which permits unrestricted use, distribution, and reproduction in any medium, provided the original work is properly cited.

A fungal tannase was produced, recovered, and immobilized by entrapment in calcium alginate beads. Catalytical properties of the immobilized enzyme were compared with those of the free one. Tannase was produced intracellularly by the xerophilic fungus Aspergillus niger GH1 in a submerged fermentation system. Enzyme was recovered by cell disruption and the crude extract was partially purified. The catalytical properties of free and immobilized tannase were evaluated using tannic acid and methyl gallate as substrates. $K_{M}$ and $V_{\max }$ values for free enzyme were very similar for both substrates. But, after immobilization, $K_{M}$ and $V_{\max }$ values increased drastically using tannic acid as substrate. These results indicated that immobilized tannase is a better biocatalyst than free enzyme for applications on liquid systems with high tannin content, such as bioremediation of tannery or olive-mill wastewater.

\section{Introduction}

Tannin acyl hydrolase (TAH) also known as tannase is an enzyme (EC 3.1.1.20) that catalyzes the hydrolysis of ester bonds present in gallotannins, complex tannins, and gallic acid esters $[1,2]$. The major applications of tannase are in the elaboration of instantaneous tea and acorn liquor, as well as in the production of gallic acid from tannin-rich agrowastes $[3,4]$. Tannase is also utilized as clarifying agent in wine, beer, fruit juices, and coffee-flavored soft drinks $[5,6]$. Moreover, it has been proposed the use of this enzyme for bioremediation of effluents from tanneries and to improve the nutritional properties of tannin-rich forage [7].

Despite the several important applications of tannase in food, feed, chemical and pharmaceutical industries, high scale use of this enzyme is severally restricted due to high production costs. Thus tannase is considered a specialty enzyme. Therefore, there is a continuous search for new sources of tannase [8-10], as well as improved methods for production, recovery, and application of the enzyme [11-13].

In order to overcome some limitations of free tannase, several attempts have been made to immobilize the enzyme on a suitable matrix [14-24]. Enzyme immobilization facilitates the efficient recovery and reuse of costly enzymes and enables their use in continuous, fixed-bed operation. Immobilized enzymes are more easy to handle and to separate from the product, thereby minimizing or eliminating protein contamination of the product. Additionally, immobilized enzymes are often more stable than the free ones, allowing the repeated reuse of the biocatalyst [25].

One of the most convenient methods for enzyme immobilization is the entrapment in Ca-alginate beads. The major advantage of this technique is the simplicity by which spherical beads can be obtained by dripping a polymercell suspension into a medium containing positively charged ions. The particles formed are transparent, mechanically stable, nontoxic, and cheap $[26,27]$. 
We previously reported the production, and purification of a novel tannase from the xerophilic fungus Aspergillus niger GH1 [28]. This enzyme showed interesting properties such as good activity and stability at high temperature, low inhibition by metal ions and other additives and considerable stability at a wide range of $\mathrm{pH}$. Therefore, in the present study, tannase from A. niger $\mathrm{GH} 1$ was immobilized in Ca alginate beads and the catalytical properties of immobilized tannase were compared with those of free enzyme.

\section{Materials and Methods}

2.1. Microorganism and Culture Conditions. Aspergillus niger $\mathrm{GH} 1$, utilized for tannase production, was obtained from the UAdeC-DIA culture collection. This strain was previously isolated from Mexican semidesert and characterized as tannase producer [29]. Fungal spores were stored at $-40^{\circ} \mathrm{C}$ in a cryoprotectant medium composed of glycerol and skim milk.

Microorganism was propagated by transferring conserved spores to Erlenmeyer flasks with Czapek-tannic acid agar and incubating at $30^{\circ} \mathrm{C}$ for $4-6$ days. After this, spores were harvested with Tween 80 (volume ratio of $0.01 \%$ ) and counted in a modified Neubauer chamber before inoculation.

Tannase was produced by A. niger in submerged culture. The culture medium for tannase contained $(\mathrm{g} / \mathrm{L})$ $\mathrm{KH}_{2} \mathrm{PO}_{4}$ : 2.19; $\left(\mathrm{NH}_{4}\right)_{2} \mathrm{SO}_{4}: 4.38 ; \mathrm{MgSO}_{4} \cdot 7 \mathrm{H}_{2} \mathrm{O}: 0.44$; $\mathrm{CaCl}_{2} \cdot 7 \mathrm{H}_{2} \mathrm{O}: 0.044 ; \mathrm{MnCl}_{2} \cdot 6 \mathrm{H}_{2} \mathrm{O}: 0.009 ; \mathrm{NaMoO}_{4} \cdot 2 \mathrm{H}_{2} \mathrm{O}$ : $0.004 ; \mathrm{FeSO}_{4} \cdot 7 \mathrm{H}_{2} \mathrm{O}$ : 0.06 . Salt solution was autoclaved at $12^{\circ} \mathrm{C}$ for $15 \mathrm{~min}$ and cooled at room temperature. Tannic acid was added to the salt solution to a final concentration of $12.5 \mathrm{~g} / \mathrm{L}$, then the $\mathrm{pH}$ was adjusted at 5.5 with $1 \mathrm{~N} \mathrm{NaOH}$, and then the culture media was sterilized again by filtration through $0.45 \mu \mathrm{m}$ nylon membranes. Tannase production was carried out in $1 \mathrm{~L}$ Erlenmeyer flasks containing $250 \mathrm{~mL}$ of culture medium inoculated with $1 \times 10^{7}$ A. niger spores $/ \mathrm{mL}$. Flasks were incubated for $24 \mathrm{~h}$ at $30^{\circ} \mathrm{C}$ with constant agitation at $250 \mathrm{rpm}$.

2.2. Tannase Recovery. Crude enzymatic extracts from SmF were obtained by filtering the biomass through Whatman no. 41 filter paper. Mycelial cells retained were washed with physiological solution, frozen with liquid nitrogen and milled in a mortar. The macerate was recovered with acetate buffer $(100 \mathrm{mM}, \mathrm{pH}=5.5)$. Crude extract was put into a $10 \mathrm{kD}$ MWCO cellulose membrane (Sigma, St. Louis, USA) and dialyzed against water. Dialyzed extract was concentrated (12.5-fold) with polyethylene glycol-6000 as described by Sharma and coworkers [30]. Concentrated extract was applied into a HiTrap G25 column, eluted with citrate buffer (100 mM, pH 5.0) and fractionated in an AKTA prime FPLC system (Amersham, Piscataway, USA).

2.3. Enzyme Immobilization. Tannase from A. niger was immobilized in Ca alginate beads. $4 \mathrm{~mL}$ of partially purified tannase $(288 \mathrm{U} / \mathrm{L})$ were mixed with $46 \mathrm{~mL}$ of $2.0 \%$ sodium alginate solution to get homogeneity. Then the mixture was added with constant agitation and a temperature of $4^{\circ} \mathrm{C}$ to $0.6 \mathrm{M} \mathrm{CaCl}_{2}$ solution as droplets using a glass burette. The beads were kept in $0.1 \mathrm{M} \mathrm{CaCl}_{2}$ at $4^{\circ} \mathrm{C}$ for about $2 \mathrm{~h}$ and then washed briefly with sterile water.

2.4. Kinetic Constants of Tannase. Values of $K_{M}$ and $V_{\max }$ were calculated for free and immobilized tannase using methyl gallate and tannic acid as substrates in citrate buffer (50 mM, pH 5.5). Hydrolysis was carried out in a $250 \mathrm{~mL}$ glass jacketed bioreactor. 50 beads of immobilized tannase or the equivalent in free enzyme was added to $100 \mathrm{~mL}$ of substrate with constant agitation and controlled temperature at $30^{\circ} \mathrm{C}$, and $1 \mathrm{~mL}$ samples were withdrawn at regular intervals. Reaction was stopped with $0.2 \mathrm{~mL}$ of $2 \mathrm{~N} \mathrm{HCl}$, and the reaction mixture was filtered through a $45 \mu \mathrm{m}$ membrane and analyzed for gallic acid by an HPLC procedure [31]. Tannase activity rate was estimated as V (IU) following the Michaelis-Menten equation. Estimation of different parameters for the equation was obtained through the linearization method of Lineweaver-Burk, using the Solver utility of the program Excel (Microsoft, Redmond, USA).

2.5. Analytical Methods. Tannase activity was assayed using HPLC methodology, essentially as described by Beverini and Metche [31] with slight modifications. In brief, the enzyme $(50 \mu \mathrm{L})$ was added to $1 \mathrm{~mL}$ of methyl gallate $3 \mathrm{mM}$. The reaction mixture was incubated at $30^{\circ} \mathrm{C}$ for $30 \mathrm{~min}$. The reaction was stopped with $2 \mathrm{M} \mathrm{HCl}$. Each sample was filtered through a $45 \mu \mathrm{m}$ membrane prior to HPLC analysis. One unit of enzyme (IU) was defined as the amount of enzyme able to release $1 \mu \mathrm{mol}$ gallic acid per minute of culture filtered under the standard assay conditions. Protein estimation was done as described by Bradford [32].

\section{Results and Discussion}

3.1. Tannase Production and Recovery. Tannase production was carried out by $A$. niger GH1 in submerged fermentation. Under the described conditions, tannase was expressed mainly intracellularly (data not shown). At the end of incubation, $1.16 \mathrm{~g}$ of biomass were obtained from $2 \mathrm{~L}$ of culture broth. After cell disruption it were recovered $200 \mathrm{~mL}$ of a crude extract with $15.68 \mathrm{IU}$ of tannase per liter and a specific activity of 7.29 IU per mg of protein.

Tannase production was significantly lower than previously reported by our group [28]. This may be related with the culture system utilized. In that case, Mata-Gómez and coworkers [28] utilized a tannase produced by $A$. niger GH1 in a solid-state fermentation system. The enzyme was produced mainly extracellularly, and the volumetric activity reached about $400 \mathrm{IU} / \mathrm{L}$. Lekha and Lonsane [33] reported that in submerged fermentation, tannase production by $A$. niger is intracellular during the first $48 \mathrm{~h}$ and the enzyme is subsequently excreted. In contrast, tannase production in solid-state fermentation is completely extracellular.

On the other hand Barthomeuf and coworkers found that, during the first hours of submerged fermentation, tannase remains strongly bound to the mycelium of Aspergillus 
TABLE 1: Kinetic constants of free and immobilized tannase.

\begin{tabular}{lcccccc}
\hline \multirow{2}{*}{ Microorganism } & \multirow{2}{*}{ Substrate } & \multicolumn{2}{c}{ Free tannase } & \multicolumn{2}{c}{ Immobilized tannase } & \multirow{2}{*}{ Reference } \\
& & $\begin{array}{c}K_{M} \\
\mathrm{mM}\end{array}$ & $\begin{array}{c}V_{\mathrm{Max}} \\
\mu \mathrm{mol} / \mathrm{min}\end{array}$ & $\begin{array}{c}K_{M} \\
\mathrm{mM}\end{array}$ & $\begin{array}{c}V_{\text {Max }} \\
\mu \mathrm{mol} / \mathrm{min}\end{array}$ & \\
\hline Rhizopus oryzae & Sal seed & $30.9^{*}$ & $4.4^{* *}$ & $39.9^{*}$ & $4.0^{* *}$ & {$[18]$} \\
Rhizopus oryzae & Myrobalan & $26.3^{*}$ & $9.4^{* *}$ & $29.0^{*}$ & $2.4^{* *}$ & {$[18]$} \\
Rhizopus oryzae & Tea leaf & $26.4^{*}$ & $0.47^{* *}$ & $30.5^{*}$ & $0.46^{* *}$ & {$[18]$} \\
Aspergillus oryzae & Tannic acid & 7.35 & 80 & 11.76 & 40 & {$[14]$} \\
Aspergillus niger & Tannic acid & 0.3 & 0.013 & 0.6 & 0.020 & {$[24]$} \\
Aspergillus niger & Tannic acid & $1.1 \times 10^{-5}$ & 416 & $1.1 \times 10^{-5}$ & 131 & {$[22]$} \\
Aspergillus niger & Tannic acid & 0.400 & 0.05 & 23.75 & 0.25 & This study \\
Aspergillus niger & Methyl gallate & 0.433 & 0.033 & 0.529 & 0.003 & This study \\
\hline
\end{tabular}

${ }^{*}$ These results are expressed as $\mathrm{mg} / \mathrm{mL}$.

**These results are expressed as $\mathrm{U} / \mathrm{mL} / \mathrm{h}$.

niger and no more than $5 \%$ of the enzyme may be removed by physical methods, such as cell disruption [34]. However, at industrial level tannase is produced mainly by submerged fermentation due to more standardized methodology and equipment.

Crude extract was subjected to a recovery process consisting of dialysis, concentration, and gel filtration chromatography. This protocol led to 5.4-fold purification and 5.6-fold concentration with a recovery yield higher than $90 \%$.

We previously reported the purification of an extracellular tannase from $A$. niger. In that case, through a protocol consisting of ultrafiltration, ionic exchange, and gel filtration chromatography, a 42 -fold purification was obtained with $0.3 \%$ yield [28]. In the present paper, we concentrated and partially purified the enzyme according with the needs of an enzyme for industrial use. Industrial enzymes require a certain degree of purity to avoid undesirable reactions and the presence of proteins and other foreign compounds in the final product. The degree of purity required is lower for immobilized enzymes due to entrapment of the biocatalyst [25].

Most of the reported protocols for tannase involve several precipitation and chromatographic steps. For example, Mahendran and coworkers purified a Paecilomyces variotii tannase by a treatment with activated charcoal followed by precipitation with ammonium sulfate, ionic exchange chromatography, and gel filtration. They obtained a 30.5 -fold purification of the enzyme, but with a recovery yield of $17.6 \%$ [20]. On the other hand, Sharma and coworkers purified a Penicillium variable tannase through a two-step procedure. They utilized ultrafiltration and gel filtration and obtained a 135-fold purification with a recovery yield of $91 \%$ [21].

3.2. Enzyme Immobilization. Tannase was efficiently immobilized in $\mathrm{Ca}$ alginate beads. During immobilization, it was obtained 253 beads of $3.5 \mathrm{~mm}$ of diameter per $\mathrm{mL}$ of enzyme extract. Since no residual activity or protein was detected in $\mathrm{CaCl}_{2}$ solution or in the wash water, it was assumed that the enzyme was completely trapped.
Recently, Schons and coworkers reported the immobilization of a Paecilomyces variotii tannase by entrapment into several polysaccharide matrixes [35]. Besides the fact that the best encapsulation efficiency (57\%) was obtained with pectin, tannase immobilized in alginate beads $(15 \%$ of encapsulation efficiency) was more efficient for hydrolysis of tannic acid.

3.3. Kinetic Constants of Tannase. Kinetic parameters of free and immobilized were evaluated at $30^{\circ} \mathrm{C}$ and a $\mathrm{pH}$ of 5.5 using tannic acid and methyl gallate as substrate. $K_{M}$ and $V_{\max }$ were obtained with the linearization method of Lineweaver-Burk. The kinetic constants are summarized in Table 1, Lineweaver-Burk plots are showed in Figures 1 and 2.

$K_{M}$ values for free enzyme using methyl gallate and tannic acid as substrate are very close among them $(0.433$ and $0.400 \mathrm{mM}$, resp.). When tannase was immobilized, these $K_{M}$ values were notoriously increased (1.3- and 59-fold for methyl gallate and tannic acid, resp.).

These results indicate that $A$. niger GH1 tannase produced in submerged fermentation has almost the same affinity for methyl gallate and tannic acid. In contrast, the tannase produced by this microorganism in solid-state fermentation has more affinity for tannic acid than for methyl gallate [28]. These catalytical disparities among the tannases could be related to differences in glycosylation among the enzyme produced in solid-state and submerged fermentation, as suggested by Renovato and coworkers [36].

The $K_{M}$ value of tannase increased significantly after immobilization in Ca alginate, especially when tannic acid was used as substrate. This is a common phenomenon during enzyme immobilization $[14,18,22,24]$. The increase of $K_{M}$ is partially due to mass transfer resistance of the substrate into the polymer matrix, and mass transfer resistance appears to be drastic in substrates such as tannins [14]. For example, Yu and coworkers [24] immobilized an A. niger tannase with a coacervate calcium alginate membrane. In that case, the $K_{M}$ value increased 4 times with immobilization. Similar results were reported by other authors (Table 1 ).

Hydrolysable tannins have the ability to complex with 


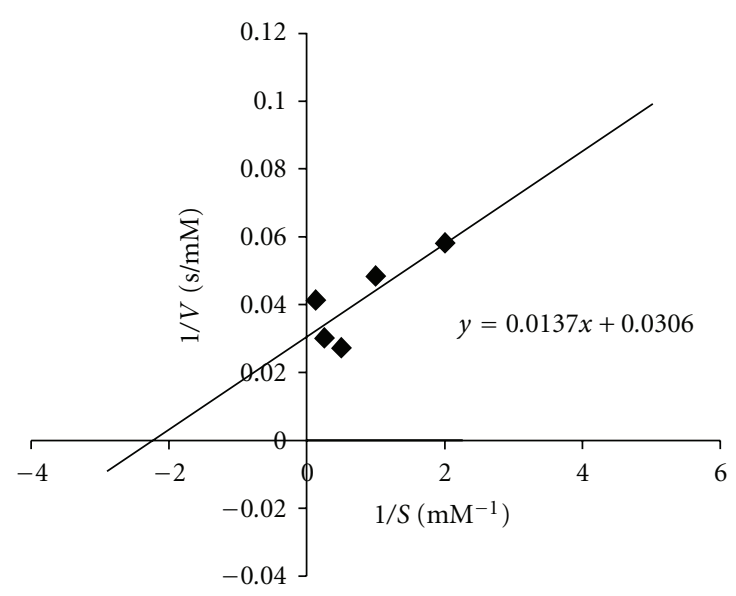

(a)

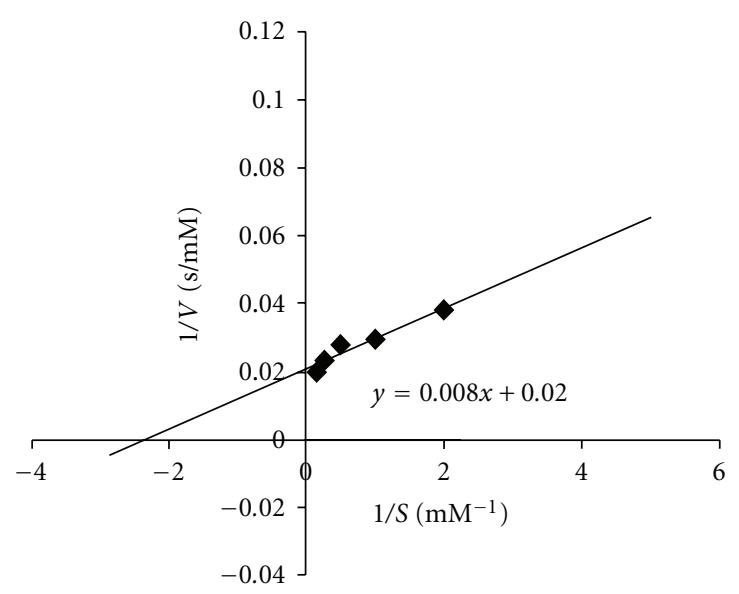

(b)

FIGURE 1: Lineweaver-Burk plots for free tannase using methyl gallate (a) and tannic acid (b) as substrate.

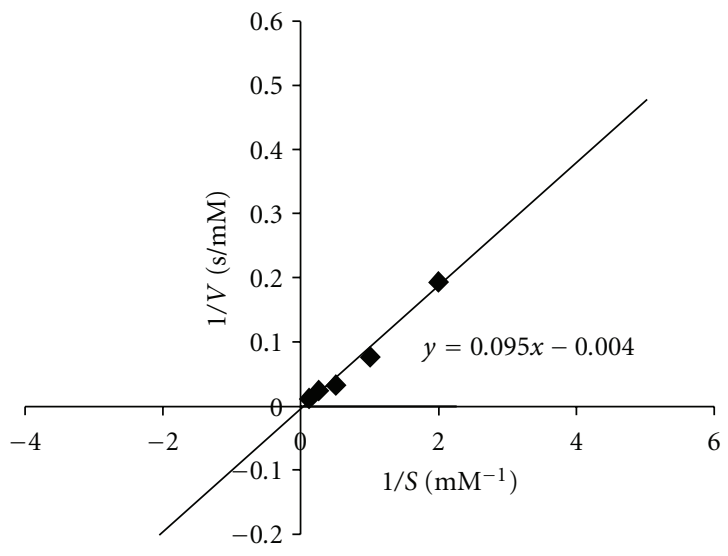

(a)

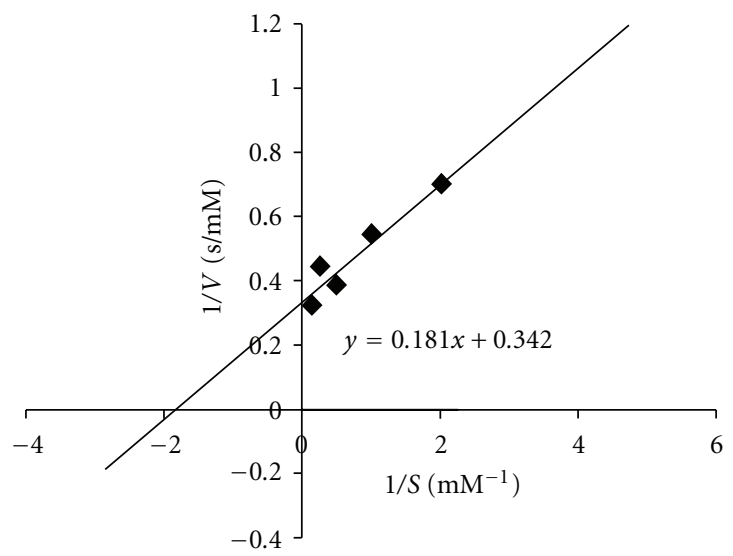

(b)

FIgURE 2: Lineweaver-Burk plots for immobilized tannase using methyl gallate (a) and tannic acid (b) as substrate.

macromolecules such as carbohydrates but, to maintain its binding capacity, tannins must have more than two acidic unit constituents esterified to the glucose core [4]. Thus, the interaction between alginate and tannic acid is much higher than that with methyl gallate, as indicated by these results.

On the other hand, the $V_{\max }$ value for intracellular tannase from $A$. niger is higher using tannic acid as substrate in both free and immobilized forms. In addition, immobilization resulted in an increase in $V_{\max }$ when tannic acid was used as substrate. Typically, immobilized enzymes have lower $V_{\max }$ values than their free counterparts [37], and this phenomenon is associated with conformational changes of the enzyme during immobilization [18]. Higher $V_{\max }$ values after immobilization have been reported for inulinase [38], invertase [39], and $\beta$-galactosidase [40]. However, this is an unusual behavior and the mechanistic basis for this positive feature requires further investigation [37].
The increase of the maximal velocity of reaction and the $K_{M}$ value makes the immobilized tannase a better biocatalyst than free enzyme for applications on liquids with high tannin content, such as bioremediation of tannery or olive-mill wastewater. In addition, the immobilization technique allows the recovery and reutilization of the enzyme.

\section{Conclusions}

Tannase was efficiently immobilized in Ca alginate beads. The immobilized enzyme presented interesting catalytical properties, different from the free enzyme. These catalytical differences could be related with mass diffusion coefficients and conformational changes of the protein as well as the interaction of the substrate with the polymer matrix. These properties of the enzyme and the possibility of recovery and reutilization make the immobilized tannase from Aspergillus 
niger GH1 an interesting biocatalyst with potential application in liquid systems with high tannin content, such as bioremediation of tannery or olive-mill wastewater.

\section{Acknowledgments}

The authors thank the financial support provided by the program SEP-CONACYT-Ciencia Basica 2005. A. Flores-Maltos, L. V. Rodríguez-Duràn, and J. Renovato thank the Mexican National Council on Science and Technology (CONACYT) for the financial support to study his Postgraduate Program at Universidad Autónoma de Coahuila.

\section{References}

[1] H. Rodríguez, J. A. Curiel, J. M. Landete et al., "Food phenolics and lactic acid bacteria," International Journal of Food Microbiology, vol. 132, no. 2-3, pp. 79-90, 2009.

[2] L. Ramírez, J. Arrizon, G. Sandoval et al., "A new microplate screening method for the simultaneous activity quantification of feruloyl esterases, tannases, and chlorogenate esterases," Applied Biochemistry and Biotechnology, vol. 151, no. 2-3, pp. 711-723, 2008.

[3] C. N. Aguilar and G. Gutiérrez-Sánchez, "Review: sources, properties, applications and potential uses of tannin acyl hydrolase," Food Science and Technology International, vol. 7, no. 5, pp. 373-382, 2001.

[4] C. N. Aguilar, R. Rodríguez, G. Gutiérrez-Sánchez et al., "Microbial tannases: advances and perspectives," Applied Microbiology and Biotechnology, vol. 76, no. 1, pp. 47-59, 2007.

[5] P. K. Lekha and B. K. Lonsane, "Production and application of tannin acyl hydrolase: state of the art," in Advances in Applied Microbiology, S. Neidleman and A. Laskin, Eds., vol. 44, pp. 215-260, Academic Press, San Diego, Calif, USA, 1997.

[6] Y. A. S. Anwar, Hasim, and I. M. Artika, "The production of tannin acyl hydrolase from Aspergillus niger," Microbiology Indonesia, vol. 10, no. 2, pp. 91-94, 2007.

[7] R. Belmares, J. C. Contreras-Esquivel, R. Rodríguez-Herrera, A. R. Coronel, and C. N. Aguilar, "Microbial production of tannase: an enzyme with potential use in food industry," LWT_Food Science and Technology, vol. 37, no. 8, pp. 857864,2004

[8] M. Kasieczka-Burnecka, K. Kuc, H. Kalinowska, M. Knap, and M. Turkiewicz, "Purification and characterization of two cold-adapted extracellular tannin acyl hydrolases from an Antarctic strain Verticillium sp. P9," Applied Microbiology and Biotechnology, vol. 77, no. 1, pp. 77-89, 2007.

[9] N. Y. Sariözlü and M. Kivanç, "Isolation of gallicacidproducing microorganisms and their use in the production of gallic acid from gall nuts and sumac," African Journal of Biotechnology, vol. 8, no. 6, pp. 1110-1115, 2009.

[10] M. Pepi, L. R. Lampariello, R. Altieri et al., "Tannic acid degradation by bacterial strains Serratia spp. and Pantoea sp. isolated from olive mill waste mixtures," International Biodeterioration and Biodegradation, vol. 64, no. 1, pp. 73-80, 2010.

[11] J. S. Purohit, J. R. Dutta, R. K. Nanda, and R. Banerjee, "Strain improvement for tannase production from co-culture of Aspergillus foetidus and Rhizopus oryzae," Bioresource Technology, vol. 97, no. 6, pp. 795-801, 2006.

[12] J. A. Curiel, L. Betancor, B. de Las Rivas, R. Muñoz, J. M. Guisan, and G. Fernández-Lorente, "Hydrolysis of tannic acid catalyzed by immobilized-stabilized derivatives of tannase from lactobacillus plantarum," Journal of Agricultural and Food Chemistry, vol. 58, no. 10, pp. 6403-6409, 2010.

[13] X. W. Yu and Y. Q. Li, "Expression of Aspergillus oryzae tannase in Pichia pastoris and its application in the synthesis of propyl gallate in organic solvent," Food Technology and Biotechnology, vol. 46, no. 1, pp. 80-85, 2008.

[14] M. A. Abdel-Naby, A. A. Sherif, A. B. El-Tanash, and A. T. Mankarios, "Immobilization of Aspergillus oryzae tannase and properties of the immobilized enzyme," Journal of Applied Microbiology, vol. 87, no. 1, pp. 108-114, 1999.

[15] F. S. Chang, P. C. Chen, R. L. C. Chen, F. M. Lu, and T. J. Cheng, "Real-time assay of immobilized tannase with a stopped-flow conductometric device," Bioelectrochemistry, vol. 69, no. 1, pp. 113-116, 2006.

[16] E. Su, T. Xia, L. Gao, Q. Dai, and Z. Zhang, "Immobilization and characterization of tannase and its haze-removing," Food Science and Technology International, vol. 15, no. 6, pp. 545552, 2009.

[17] L. H. Guo and S. K. Yang, "Study on gallic acid preparation by using immobilized tannase from Aspergillus niger," Chinese Journal of Biotechnology, vol. 16, no. 5, pp. 614-617, 2000.

[18] S. K. Hota, J. R. Dutta, and R. Banerjee, "Immobilization of tannase from Rhizopus oryzae and its efficiency to produce gallic acid from tannin rich agro-residues," Indian Journal of Biotechnology, vol. 6, no. 2, pp. 200-204, 2007.

[19] L. C. Katwa, M. Ramakrishna, and M. R. R. Rao, "Spectrophotometric assay of immobilized tannase," Journal of Biosciences, vol. 3, no. 2, pp. 135-142, 1981.

[20] B. Mahendran, N. Raman, and D. J. Kim, "Purification and characterization of tannase from Paecilomyces variotii: hydrolysis of tannic acid using immobilized tannase," Applied Microbiology and Biotechnology, vol. 70, no. 4, pp. 444-450, 2006.

[21] S. Sharma, L. Agarwal, and R. K. Saxena, "Purification, immobilization and characterization of tannase from Penicillium variable," Bioresource Technology, vol. 99, no. 7, pp. 2544-2551, 2008.

[22] S. Sharma, T. K. Bhat, and M. N. Gupta, "Bioaffinity immobilization of tannase from Aspergillus niger on concanavalin A-Sepharose CL-4B," Biotechnology and Applied Biochemistry, vol. 35, no. 3, pp. 165-169, 2002.

[23] A. Srivastava and R. Kar, "Application of immobilized tannase from Aspergillus niger for the removal of tannin from myrobalan juice," Indian Journal of Microbiology, vol. 50, 1, pp. 46-51, 2010.

[24] X. Yu, Y. Li, C. Wang, and D. Wu, "Immobilization of Aspergillus niger tannase by microencapsulation and its kinetic characteristics," Biotechnology and Applied Biochemistry, vol. 40, no. 2, pp. 151-155, 2004.

[25] R. A. Sheldon, "Enzyme immobilization: the quest for optimum performance," Advanced Synthesis and Catalysis, vol. 349, no. 8-9, pp. 1289-1307, 2007.

[26] P. K. D. Mohapatra, K. C. Mondal, and B. R. Pati, "Production of tannase by the immobilized cells of Bacillus licheniformis KBR6 in Ca-alginate beads," Journal of Applied Microbiology, vol. 102, no. 6, pp. 1462-1467, 2007.

[27] P. S. Panesar, S. Kumari, and R. Panesar, "Potential applications of immobilized $\beta$-galactosidase in food processing industries," Enzyme Research, vol. 2010, Article ID 473137, 16 pages, 2010.

[28] M. A. Mata-Gómez, L. V. Rodríguez, E. L. Ramos et al., "A novel tannase from the xerophilic fungus Aspergillus niger 
GH1," Journal of Microbiology and Biotechnology, vol. 19, no. 9, pp. 987-996, 2009.

[29] M. Cruz-Hernández, J. C. Contreras-Esquivel, F. Lara, R. Rodríguez, and C. N. Aguilar, "Isolation and evaluation of tannin-degrading fungal strains from the Mexican desert," Zeitschrift fur Naturforschung, Section C, vol. 60, no. 11-12, pp. 844-848, 2005.

[30] S. Sharma, T. K. Bhat, and R. K. Dawra, "Isolation, purification and properties of tannase from Aspergillus niger van Tieghem," World Journal of Microbiology and Biotechnology, vol. 15, no. 6, pp. 673-677, 1999.

[31] M. Beverini and M. Metche, "Identification, purification, physiochemical properties of tannase from Aspergillus oryzae," Science des Aliments, vol. 10, no. 1, pp. 708-816, 1990.

[32] M. M. Bradford, "A rapid and sensitive method for the quantitation of microgram quantities of protein utilizing the principle of protein dye binding," Analytical Biochemistry, vol. 72, no. 1-2, pp. 248-254, 1976.

[33] P. K. Lekha and B. K. Lonsane, "Comparative titres, location and properties of tannin acyl hydrolase produced by Aspergillus niger PKL 104 in solid-state, liquid surface and submerged fermentations," Process Biochemistry, vol. 29, no. 6, pp. 497-503, 1994.

[34] C. Barthomeuf, F. Regerat, and H. Pourrat, "Production, purification and characterization of a tannase from Aspergillus niger LCF 8," Journal of Fermentation and Bioengineering, vol. 77, no. 3, pp. 320-323, 1994.

[35] P. F. Schons, F. C. R. Lopes, V. Battestin, and G. A. Macedo, "Immobilization of tannase from Paecilomyces variotii by ionic gelation," in Proceedings of the 18th International Conference on Bioencapsulation, p. 63, Porto, Portugal, October 2010.

[36] J. Renovato, G. Gutiérrez-Sánchez, L. V. Rodríguez-Durán, C. Bergman, R. Rodríguez, and C. N. Aguilar, "Differential properties of Aspergillus niger tannase produced under solidstate and submerged fermentations," Applied Biochemistry and Biotechnology. In press.

[37] M. Tu, X. Zhang, A. Kurabi, N. Gilkes, W. Mabee, and J. Saddler, "Immobilization of $\beta$-glucosidase on Eupergit C for lignocellulose hydrolysis," Biotechnology Letters, vol. 28, no. 3, pp. 151-156, 2006.

[38] F. V.A. Risso, M. A. Mazutti, F. Costa, H. Treichel, F. Maugeri, and M. I. Rodrigues, "Comparative studies of the stability of free and immobilized inulinase from Kluyveromyces marxianus nrrl y-7571 in aqueous-organic solutions," Brazilian Journal of Chemical Engineering, vol. 27, no. 4, pp. 507-516, 2010.

[39] M. de Los Ángeles Calixto-Romo, J. A. Santiago-Hernández, V. Vallejo-Becerra, L. Amaya-Delgado, M. del Carmen MontesHorcasitas, and M. E. Hidalgo-Lara, "Expression, purification and immobilization of the intracellular invertase INVA, from Zymomonas mobilis on crystalline cellulose and Nylon-6," Journal of Industrial Microbiology and Biotechnology, vol. 35, no. 11, pp. 1455-1463, 2008.

[40] M. M. Elnashar and M. A. Yassin, "Lactose hydrolysis by $\beta$ galactosidase covalently immobilized to thermally stable biopolymers," Applied Biochemistry and Biotechnology, vol. 159, no. 2, pp. 426-437, 2009. 

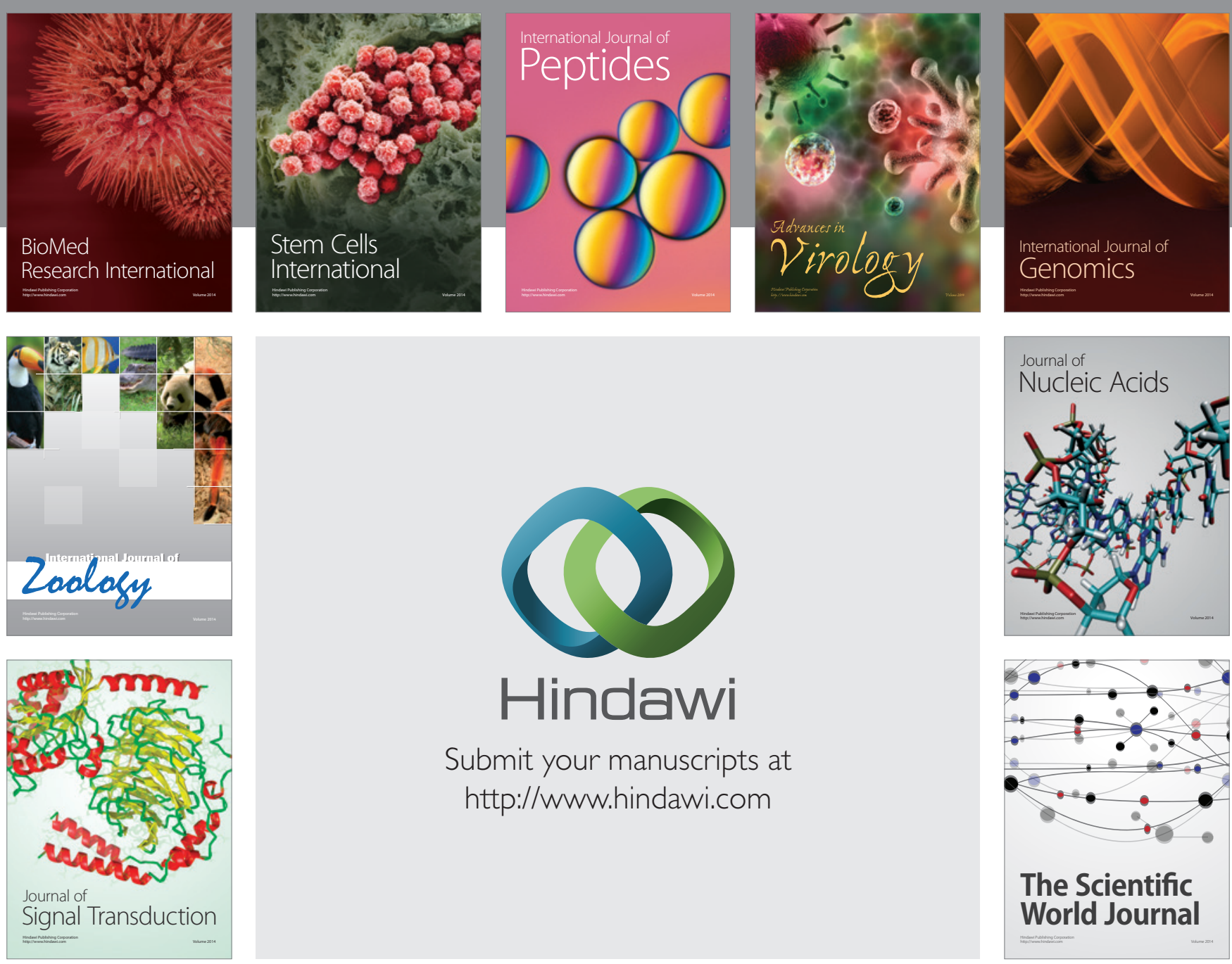

Submit your manuscripts at

http://www.hindawi.com
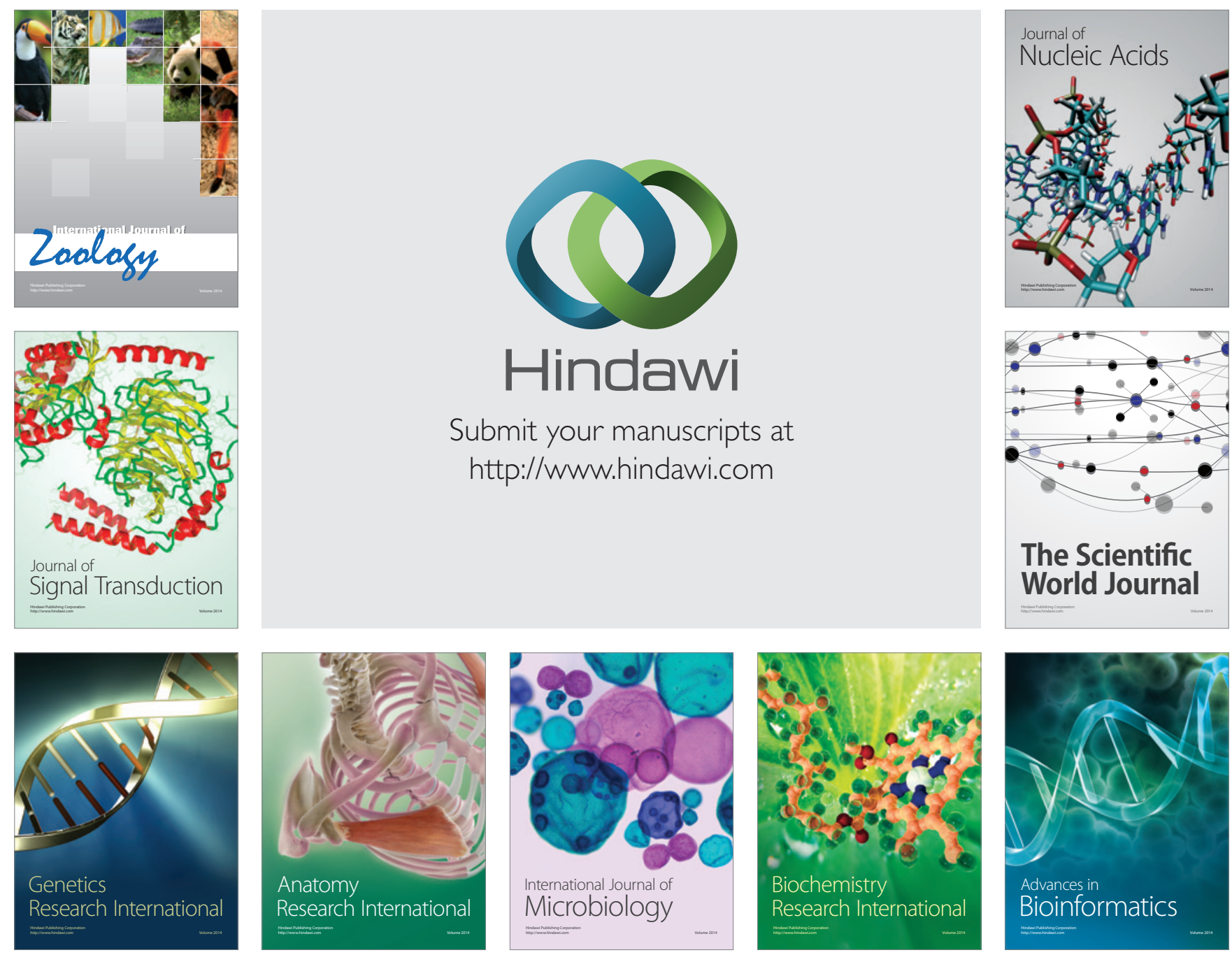

The Scientific World Journal
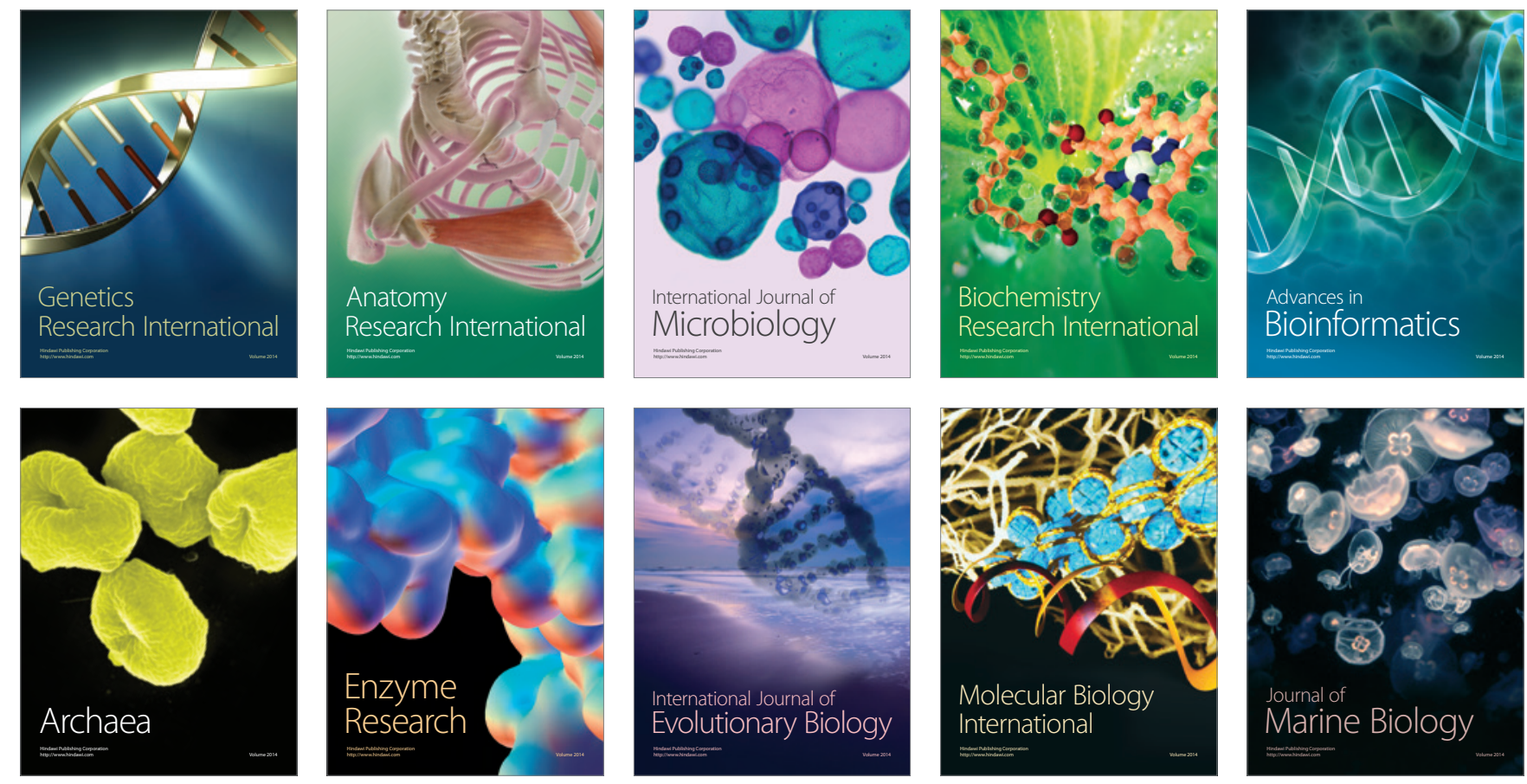